\title{
PENGARUH PENERAPAN STRATEGI METAKOGNITIF TERHADAP KEMAMPUAN PEMECAHAN MASALAH MATEMATIS BEDASARKAN KEMANDIRIAN BELAJAR SISWA
}

\author{
Anisah Meisura ${ }^{1} \bowtie$ Risnawati $^{2}$, dan Zubaidah Amir $\mathbf{M Z}^{3}$ \\ ${ }^{1,2,3}$ Prodi Pendidikan Matematika, Universitas Islam Negeri Sultas Syarif Kasim Riau
}

\begin{abstract}
Info Artikel Abstract
Sejarah Artikel:

Diterima 16 Mar 2019

Direvisi 22 Mei 2019

Disetujui 25 Mei 2019

Keywords: problem solving ability,

metakognitif strategy,

learning independence

Paper type:

Research paper

This research aimed at investigating whether there was or not a difference on mathematic problem solving ability between students taught by using metakognitif strategy and those who were taught by using conventional learning, knowing whether there was or not a difference on mathematic problem solving ability between students taught by using metakognitif strategy and those who were taught by using conventional learning derived from learning independence, and seeing whether there is an interaction between metacognitive strategies and learning independence in influencing students' mathematical problem solving abilities. This research was a Quasi-experiment with The Nonequivalent Posttest Only Control Group Design. design. All of the tenth-grade students of MIA class in the second semester of the Academic Year of 2018/2019. Samples selected purposive sampling were the tenth-grade students of MIA 1 and 2 classes. The data analysis that was used for the first hypothesis was t-test, two-way ANOVA was for the second and the third hypotheses. The data analysis result that $t$-test was used showed that $t_{\text {observed }}=3.309$ was higher than $t_{\text {table }}=1.9977$. So, it could be concluded that there was a difference on mathematic problem solving ability between students taught by using metakognitif strategy and those who were taught by using conventional learning. The data analysis result that two-way ANOVA was used showed that menunjukkan $F(B)_{\text {observed }}=40.45$ was higher than $F(B)_{\text {table }}$ $=3.15$ So, it could be concluded that there was a difference on mathematic problem solving skill between students taught by using metakognitif strategy and those who were taught by using conventional learning derived from learning independence. For interaction, $F(A \times B)_{\text {observed }}=0.47$ was lower than $F(A \times B)_{\text {tabel }}=3.15$ so that it can be shown that there is no interaction between metacognitive strategies and independence of learning in influencing students mathematical problem solving abilities.
\end{abstract}

\begin{abstract}
Abstrak
Tujuan penelitian ini adalah untuk menyelidiki ada tidaknya perbedaan kemampuan pemecahan masalah matematis siswa yang mengikuti strategi metakoginitif dengan siswa yang mengikut pembelajaran konvensional, mengetahui ada tidaknya perbedaan kemampuan pemecahan masalah matematis antara siswa yang memiliki kemandirian belajar tinggi, sedang dan rendah serta melihat ada tidaknya interaksi antara strategi metakognitif dan kemandirian belajar dalam mempengaruhi kemampuan pemecahan masalah matematis siswa. Penelitian ini merupakan penelitian Quasi Eksperimental dengan desain The Nonequivalent Posttest Only Control Group Design. Populasi dalam penelitian ini adalah seluruh siswa kelas X semester genap MAN 1 Pekanbaru tahun ajaran 2018/2019. sampel diambil secara purposive sampling adalah kelas X MIA 1 dan X MIA 2. Analisis data yang digunakan untuk hipotesis 1 menggunakan uji-t sedangkan untuk hipotesis 2 dan 3 menggunakan anova dua arah. Hasil analisis data dengan menggunakan uji-t hipotesis 1 menunjukkan $\mathrm{t}_{\text {hitung }}=3.309 \mathrm{t}_{\text {tabel }}=1.9977$. sehingga dapat disimpulkan terdapat perbedaan kemampuan pemecahan masalah matematis antara siswa yang mengikuti pembelajaran strategi metakognitif dengan siswa yang mengikuti pembelajaran konvensional. Hasil analisis data dengan menggunakan anova dua arah menunjukkan $\mathrm{F}(\mathrm{B})$ hitung $=40.45$ lebih dari $\mathrm{F}(\mathrm{B})$ table $=3.15$ dengan demikian dapat diambil kesimpulan bahwa terdapat perbedaan kemampuan pemecahan masalah matematis antara siswa yang memiliki kemandirian belajar tinggi, sedang dan rendah. Sedangkan interaknsi $F(A \times B)_{\text {hitung }}=0.47$ lebih dari $F(A \times B)_{\text {tabel }}=3.15$ sehingga dapat ditunjukan bahwa tidak terdapat interaksi antara strategi metakognitif dan kemandirian belajar dalam mempengaruhi kemampuan pemecahan masalah matematis siswa.
\end{abstract}

(C) 2019 Universitas Muria Kudus

\footnotetext{
${ }^{\square}$ Alamat korespondensi:

p-ISSN 2615-4196

Program Studi Pendidikan Matematika, Universitas Muria Kudus

e-ISSN 2615-4072

Kampus UMK Gondangmanis, Bae Kudus Gd. L. 1t I PO. BOX 53 Kudus

Tlp (0291) 438229 ex.175 Fax. (0291) 437198

E-mail: anisauyak@gmail.com
} 


\section{PENDAHULUAN}

Matematika merupakan ilmu pengetahuan yang turut memberikan sumbangan signifikan terhadap perkembangan ilmu pengetahuan dan pembangunan sumber daya manusia. Pada saat ini kemajuan ilmu dan teknologi tidak terlepas dari berkembangnya ilmu pengetahuan matematika. Misalnya dalam berbagai aplikasi dan program komputer tidak lepas dari penerapan aplikasi matematika, diantaranya operasi aljabar boolean, teori graf, matematika diskret, logika simbolik, peluang dan statistika. Matematika merupakan salah satu pengetahuan umum minimum yang harus dikuasai warga negara agar dapat berkedudukan sejajar dengan warga negara yang lain (Erman Suhuerman, 2001:60). Hal ini menandakan bahwa untuk dapat memiliki kehidupan yang layak, setiap warga negara wajib menguasai matematika.

Maka dari itu matematika menjadi bagian yang tidak dapat dipisahkan dari kehidupan manusia. Dengan belajar matematika siswa dapat berlatih menggunakan pikirannya secara logis, analitis, sistematis, kritis dan kreatif serta memiliki kemampuan bekerjasama dalam menghadapi berbagai masalah. Sebagaimana diketahui ilmu matematika banyak digunakan untuk menyelesaikan masalah dalam kehidupan sehari-hari. Tujuan pembelajaran matematika di sekolah adalah agar siswa mampu: memahami konsep matematika, menjelaskan keterkaitan antar konsep; menggunakan penalaran pada pola dan sifat, melakukan manipulasi matematika dalam membuat generalisasi, menyusun bukti, atau menjelaskan gagasan dan pernyataan matematika; memecahkan masalah matematis; mengkomunikasikan gagasan dengan simbol, tabel, diagram, atau media lain untuk memperjelas keadaan atau masalah; memiliki sikap menghargai kegunaan matematika dalam kehidupan (Depdiknas, 2008). Penjelesan di atas menunjukkan bahwa salah satu kemampuan yang harus dimiliki dan penting dikembangkan peserta didik adalah kemampuan pemecahan masalah.

Menurut Permendikbud Nomor 21 Tahun

2016, kemampuan pemecahan masalah merupakan salah satu tujuan pembelajaran matematika di sekolah. Permendikbud Nomor 21 Tahun 2016 tentang Standar Isi Pendidikan Dasar dan Menengah menetapkan bahwa kompetensi yang harus dicapai pada pelajaran matematika adalah sebagai berikut: (KEMENDIKBUD, 2016: 116-119)

1. Menunjukkan sikap logis, kritis, analitis, kreatif, cermat dan teliti, bertanggung jawab, responsif, dan tidak mudah menyerah dalam memecahkan masalah.

2. Memiliki rasa ingin tahu, semangat belajar yang kontinu, rasa percaya diri, dan ketertarikan pada matematika.

3. Memiliki rasa percaya pada daya dan kegunaan matematika, yang terbentuk melalui pengalaman belajar.

4. Memiliki sikap terbuka, objektif dalam interaksi kelompok maupun aktivitas seharihari.

5. Memiliki kemampuan mengkomunikasikan gagasan matematika dengan jelas.

Pada dasarnya kemampuan pemecahan masalah matematika merupakan satu kemampuan matematis yang penting dan perlu dan dikuasai oleh siswa yang belajar matematika. Hal yang mendasari kebenaran peryataan tersebut adalah: (Heris Hendriana dkk, 2017: 43)

1. Pemecahan masalah matematik merupakan kemampuan yang tercantum dalam kurikulum dan tujuan pembelajaran matematika baik KTSP tahun 2006, Kurikulum Matematika 2013 dan NCTM tahun 1995.

2. Pemecahan masalah matematis meliputi metode, prosedur dan strategi yang merupakan proses inti utama dalam kurikulum matematika atau merupakan tujuan umum pembelajaran matematika, bahkan sebagai jantungnya matematika. Selain itu pemecahan masalah merupakan satu kemampuan dasar dalam pembelajaran matemetika.

3. Kemampuan pemecahan masalah matematis membantu individu berpikir analitik.

4. Belajar pemecahan masalah matematis pada hakikatkanya adalah belajar berpikir, bernalar, dan menerapkan pengetahuan yang telah dimiliki.

5. Pemecahan masalah matematis membantu berpikir kritis, kreatif, dan mengembangkan kamempuan matematis lainnya.

Dalam matematika mempelajari penyelesaian masalah merupakan sesuatu yang penting, karena penyelesaian masalah merupakan satu aspek yang pasti dihadapi (Effandi Zakaria dkk, 2007: 112). Matematika dan masalah merupakan sesuatu yang memiliki fungsi satu sama lain. Namun tidak setiap persoalan dikatakan sebagai masalah, tetapi masalah adalah persoalan yang dalam memecahkannya membutuhkan analisis tidak hanya menggunakan sebab-akibat. Kemampuan pemecahan masalah dalam matematika merupakan sebuah proses dari siswa untuk menemukan sebuah jawaban 
berdasarkan langkah-langkah pemecahan masalah (Aisha Juliani dan Norlaila, 2014: 253). Berdasarkan uraian tersebut, salah satu dari kemampuan yang harus dimiliki siswa setelah mengikuti pembelajaran matematika adalah kemampuan dalam memecahkan masalah. Dan kemampuan-kemampuan lainnya ditunjukan agar siswa dapat menggunakan kemampuan tersebut dalam memecahkan masalah. Sehingga dapat dikatakan bahwa fokus utama dalam pembelajaran matematika adalah mengembangkan kemampuan pemecahan masalah.

Namun beradasarkan hasil survei yang dilakukan oleh Programme for International Student Assesment (PISA) pada tahun 2012, menempatkan Indonesia pada urutan ke-64 dari 65 negara peserta dengan nilai rata-rata 375. Hasil survei PISA yang rendah tersebut menunjukkan bahwa siswa Indonesia lemah dalam menyelesaikan soal-soal matematika pada PISA yang lebih banyak mengukur kemampuan menalar, pemecahan masalah, berargumentasi, dan berkomunikasi (Rogers Pakpahan, 2012: 335). Serta menurut hasil studi internasional yang dilakukan Trends International Mathematics and Science Study (TIMSS) dalam bidang matematika yang mengukur pemahaman, representasi, penalaran dan pemecahan masalah matematis siswa tahun 2015, menempatkan Indonesia pada peringkat 45 dari 50 negara dengan perolehan 397 point (Ina, V S Mullis, dkk, 2016:13). Sedangkan pada tahun-tahun sebelumnya berada pada peringkat 34 dari 45 negara (2003), peringkat 36 dari 45 negara (2007) dan peringkat 38 dari 42 negara (2011) (Marten Kanginan,2016:iii).

Penelitian terdahulu juga menunjukkan bahwa kemampuan pemecahan masalah matematis masih rendah. Risnawati dkk mengatakan dalam jurnalnya Pengembangan LKS Pemecahan Masalah Kaidah Pencacahan Dengan Pendekatan Metakognitif Untuk Sma Kelas XI di Pekanbaru masih banyak ditemukannya siswa yang belum mampu dalam memecahkan masalah matematika berbentuk soal cerita tersebut. Rendahnya kemampuan siswa dalam memecahkan masalah matematika dalam bentuk soal cerita bukan hanya terjadi pada siswa SD, tetapi juga dialami oleh siswa SMP dan SMA (Risnawati dkk, 2016: 139). Selanjutnya Siti Mawaddah dan Hana Anisah berpendapat bahwa hanya sebagian kecil siswa kelas VII yang membuat rencana pemecahan masalah pada saat menjawab soal matematika. Beberapa siswa juga sulit dalam memecahkan masalah matematika yang tidak rutin (Siti Mawaddah \& Hana Anisah, 2015: 167).

Berdasarakan penelitian yang dilakukan di MAN 1 Pekanbaru ada beberapa point yang didapatkan oleh peneliti. Hal ini dapat dilihat pada gambar berikut:

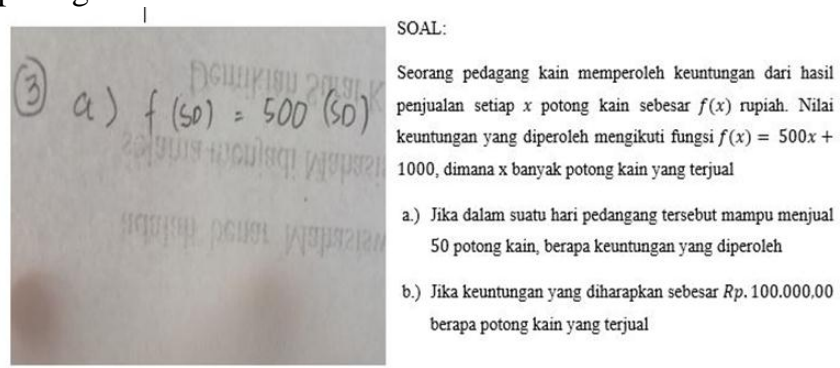

Gambar 1 Lembar Jawaban Siswa
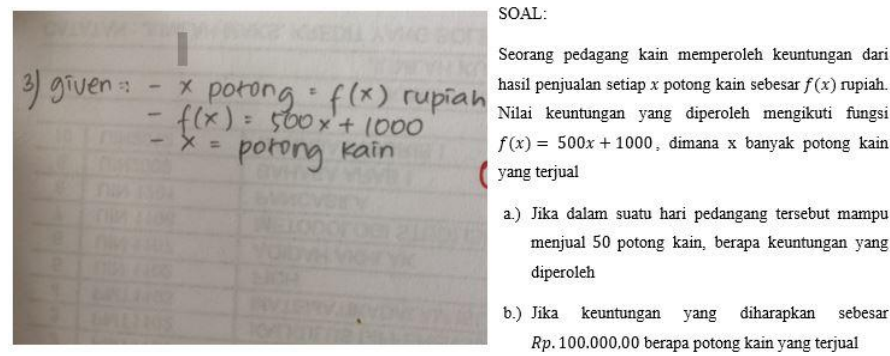

Gambar 2 Lembar Jawaban Siswa

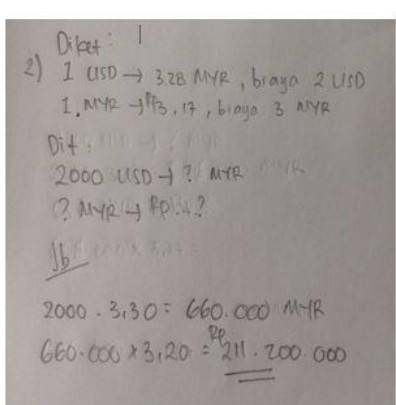

SOAL:

Suatu bank di Amerika menawarkan harga tukar dollar amerika (USD) ke ringgit malaysia (MYR), Yaitu 1 USD $=3.28 \mathrm{MYR}$ dengan biaya penukaran sebesar 2 USD untuk setiap transaksi penukaran. Kemudian salah satu bank di Malaysia menawarkan harga tukar ringgit malaysia (MYR) ke Rupiah indonesia (IDR), yaitu $1 \mathrm{MYR}=\mathrm{Rp} .3 .170$ dengan biaya penukaran sebesar 3 MYR untuk setiap penukakaran

Seorang turis asal Amerika ingin bertamasya ke malaysia kemudian melanjutkan ke indonesia dengan membawa uang sebesar 2000 USD. Berapa IDR yang akan diterima turis jika pertama dia menukar semua uangnya ke mata uang ringgit kemudian menukarnya ke rupiah di Malaysia. dan buatlah model matematika dari permasalahan diatas.

Gambar 3 Lembar Jawaban Siswa

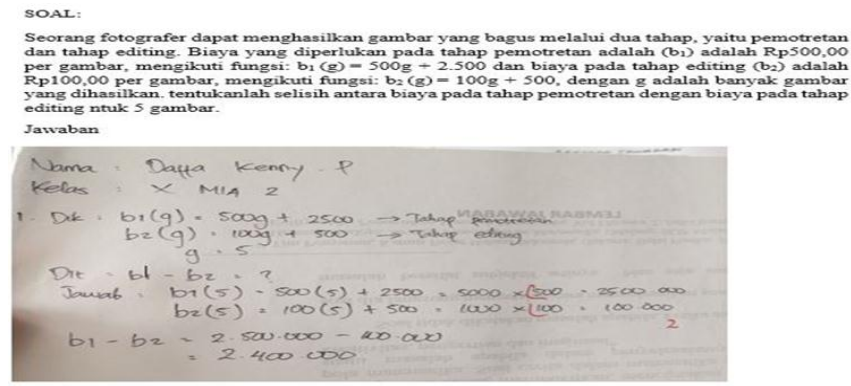

Gambar 4 Lembar Jawaban Siswa 


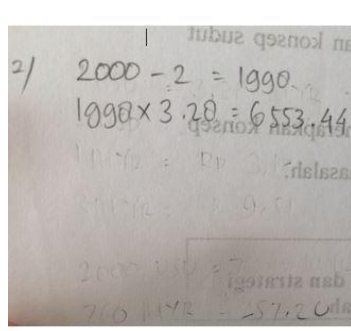

Suatu bank di Amerika menawarkan harga tukar dollar amerika (USD) ke ringgit malaysia (MYR). Yaitu 1 USD $=3.28 \mathrm{MYR}$ dengan biaya penukaran sebesar 2 USD untuk setiap transaks penukaran. Kemudian salah satu bank di Malaysia menawarka harga tukar ringgit malaysia (MYR) ke Rupiah indonesia (IDR) yaitt $1 \mathrm{MVR}=\mathrm{Rp} .3 .170$ dengan biaya penutaran seber 3 Mirk

Seorang turis asal Amerika ingin bertamasya ke malaysia kemudian melanjutkan ke indonesia dengan membawa uan sebesar 2000 USD. Berapa IDR yang akan diterima turis jika pertama dia menukar semua uangnya ke mata uang ringeit kemudian menukarnya ke rupiah di Malaysia dan buatle model matematika dari permasalahan diatas.

Gambar 5 Lembar Jawaban Siswa

SOAL:

Diketahui fungsi $f: A \rightarrow B$ merupakan fungsi bijektif, fungsi $g: C \rightarrow D$ merupakan fungs njeltif dan fingsi $h, E \rightarrow F$ mernuakan fungsi surjeltif yang di gambarkan seperti berint

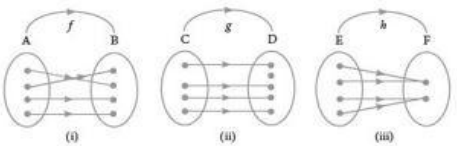

- jika fungsi invers $f$ memetakan $\mathrm{B}$ ke $\mathrm{A}$, fungsi invers $g$ memetakan $\mathrm{D}$ ke $\mathrm{C}$, dan fungsi invers $h$ memetakan $\mathrm{F}$ ke $\mathrm{E}$, maka gambarlah ketiga invers fungsi tersebut. b. Dari ketiga invers fungsi tersebut, tentukanlah mana yang merupakan fungs Jawaban

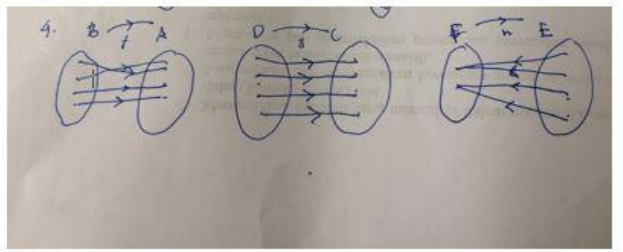

Gambar 6 Lembar Jawaban Siswa

SOAI

Diketahui fungsi $f: A \rightarrow B$ merupakan fungsi bijektif, fungsi $g: C \rightarrow D$ merupakan fungsi
injektif dan fungsi $h: E \rightarrow F$ merupakan fungsi surjektif yang di gambarkan seperti berikut

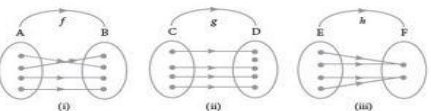

jika fungsi invers $f$ memetakan $\mathrm{B}$ ke A, fungsi invers $g$ memetakan $\mathrm{D}$ ke C, dan fungsi invers $h$ memetakan $F$ ke $E$, maka gambarlah ketiga invers fungsi tersebut.

$$
\text { Jawaban }
$$

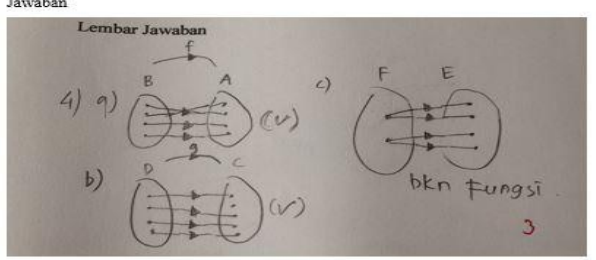

Gambar 7 Lembar Jawaban Siswa

Pada gambar 1 dan gambar 2 dapat dilihat bahwa siswa kebingungan dalam memahami unsur-unsur yang diketahui maupun ditanya di dalam soal. Sehingga untuk melakukan langkah selanjutnya dari pemecahan masalah yaitu merencanakan atau menyusun strategi dari permasalahan, siswa masih belum mampu. Pada gambar 3, gambar 4 dan gambar 5 dapat terlihat ketika diberikan soal berbasis kemampuan pemecahan masalah siswa kurang berhasil dalam membuat perencanaan penyelesaian yang baik, sehingga tidak didapatkan hasil dari penyelesaian masalah yang benar. Pada gambar 6 dan 7 dapat terlihat bahwa siswa sudah mampu merencanakan strategi namun dalam pengerjaan strategi yang sudah direncakan terdapat beberapa langkah yang tidak dilakukan, sehingga tidak didapatkan hasil dari penyelesaian masalah yang benar.

Karena kurangnya 3 kemampuan siswa yang merupakan indikator dari kemampuan pemecahan masalah, yaitu memahami masalah, membuat rencana pemecahan masalah dan melaksanakan rencana pemecahan masalah maka peneliti menyimpulkan bahwa kemampuan pemecahan masalah di MAN 1 Pekanbaru masih tergolong rendah.

Menurut peneliti untuk dapat mengatasi permasalahan tentang rendahnya kemampuan pemecahan masalah siswa perlu dilakukan pembaharuan pembelajaran. Kemampuan penyelesaian masalah siswa sangat tergantung pada kesadarannya tentang apa yang diketahuinya dan bagaimana melakukannya. Pembaharuan pembelajaran, yang dimana pada pembelajaran tersebut lebih banyak melibatkan siswa secara aktif dan kesadaraan siswa terhadap apa yang dia pelajari dalam proses pembelajaran. Maka menurut peneliti strategi yang cocok untuk permasalahan diatas adalah menerapkan strategi metakognitif.

Pada dasarnya pembelajaran dengan strategi metakognitif memberikan penekanan pada kesadaran berpikir seseorang terhadap kemampuannya untuk mengembangkan berbagai cara yang mungkin ditempuh dalam memecahkan masalah mulai dari tahap perencanaan, memilih strategi yang tepat sesuai masalah yang dihadapi, kemudian memonitor kemajuan dalam belajar dan secara bersamaan mengoreksi jika ada kesalahan yang terjadi selama memahami konsep (MS. Noto: h.47). Melalui pembelajaran dengan strategi metakognitif, siswa diarahkan melalui pertanyaan-pertanyaan yang diajukan oleh guru, seperti pertanyaan: "Apa yang saya kerjakan?", "Mengapa saya mengerjakan ini?", "Hal apa saja yang bisa membantu saya dalam menyelesaikan masalah ini?" dengan pertanyaan-pertanyaan ini akan merangsang kemampuan pemecahan masalah siswa (Erman Suherman:96)

Berdasarkan uraian permasalahan yang dikemukakan selain menerapkan strategi metakognitif dalam pembelajaran, terdapat beberapa aspek afektif yang dapat 
mempengaruhi kemampuan pemecahan masalah matematis. Aspek yang diambil dalam penelitian ini adalah kemampuan kemandirian belajar siswa. kemandirian belajar dapat didefenisikan sebagai cara siswa untuk menunjukkan rasa tanggung jawab dalam mengatur, mendisiplinkan diri, serta kemampuan siswa dalam mengembangkan kemampuan belajarnya atas kemauannya sendiri (Zubaidah Amir dan Risnawati, 2015:168). Kemandirian belajar matematika menjadi salah satu faktor penting yang menentukan keberhasilan belajar siswa khususnya yang terkait dengan kemampuan pemecahan masalah matematik siswa. matematika yang kemudian secara akumulatif akan meningkatkan kemampuan dan disposisi matematika lainnya pada siswa, termasuk kemampuan pemecahan masalah siswa. (Utari Sumarmo: 2013, 120).

Pengembangan kemandirian belajar sangat diperlukan oleh individu yang belajar matematika karena akan berdampak efektif dan efisien dalam mengatur proses belajarnya sehingga menjadi lebih baik lagi (Sri Delina: 2015,102). Sejalan dengan pernyataan diatas Utari Sumarmo mengatakan meningkatkan kemandirian belajar matematika yang kemudian secara akumulatif akan meningkatkan kemampuan dan disposisi matematika lainnya pada siswa, termasuk kemampuan pemecahan masalah siswa. (Utari Sumarmo, 120). Dengan demikian dapat disimpulkan bahwa kemandirian belajar siswa dapat mempengaruhi kemampuan pemecahan masalah matematika siswa. Kemandirian belajar siswa pada penelitian ini dikategorikan ke dalam tiga kelompok, yaitu tinggi, sedang dan rendah. Pengelompokan ini bertujuan untuk melihat tingkat keberhasilan dan pengaruh bersama dari penerapan strategi metakognitif di setiap kategori kemandirian belajar siswa terhadap kemampuan kemandirian.

Adapun rumusan masalah pada penelitian ini Apakah terdapat perbedaan kemampuan pemecahan masalah matematis antara siswa mengikuti pembelajaran strategi metakognitif dengan siswa yang menggunakan pembelajaran konvensional?, Apakah terdapat perbedaan kemampuan pemecahan masalah matematis antara siswa yang memiliki kemandirian belajar tinggi, sedang dan rendah?, Apakah terdapat interaksi antara strategi metakognitif dan kemandirian belajar siswa dalam mempengaruhi kemampuan pemecahan masalah matematis?.

\section{METODE PENELITIAN}

Metode dalam penelitian ini adalah kuasi eksperimen, desain penelitian yang dilakukan adalah The Nonequivalent Posttest Only Control Group Design. Sampel dipilih secara purposive sampling atau teknik penentuan sampel dengan pertimbangan tertentu. (Sugiyono, 2014:14). Sampel dalam penelitian ini adalah 2 kelas di salah satu sekolah MAN 1 Pekanbaru, kelas eksperimen merupakan kelas yang mendapat pembelajaran dengan strategi metakognitif sedangkan kelas kontrol merupakan kelas dengan pembelajaran konvensional. Siswa pada kelas eksperimen sebanyak 32 siswa sedangkan siswa pada kelas kontrol sebanyak 34 siswa. Terdapat 3 kali pertemuan (12 JP) dalam topik perbandingan trigometri. Sebelum perlakuan diberikan tes kemampuan pemecahan masalah sebanyak 5 soal yang sudah di uji coba (validasi, reliabel, tingkat kesukaran soal dan daya pembeda) dan peneliti memberikan angket kemandirian yang mana angket ini akan berguna untuk menentukan tinggi rendah sedang kemampuan kemandirian siswa.

Indikator kemampuan pemecahan masalah dalam penelitian ini yaitu: 1) Memahami masalah; 2) Membuat rencana penyelesaian (strategi);3) Menerapkan strategi untuk menyelesaikan masalah; 4) Memeriksa kebenaran solusi. sedangkan indikator kemandirian belajar yaitu:1) Inisiatif belajar;2) Mendiagnosa kebutuhan belajar; 3) Menetapkan tujuan belajar;4) Memilih dan menggunakan sumber; 5) Memilih dan menerapkan strategi belajar; 6) Belajar mandiri; 7) Bekerjsama dengan orang lain; 8) Mengontrol diri.

\section{HASIL DAN PEMBAHASAN}

Dalam bagian ini akan dijelaskn pengolahan data dengan uji t dan anova dua arah untuk menjawab ketiga rumusan masalah. adapun rumus uji t dan anova dua arah sebagai berikut:

Uji t

$t_{0}=\frac{M_{x}-M_{y}}{\sqrt{\left[\frac{S D_{x}}{\sqrt{N-1}}\right]^{2}+\left[\frac{S D_{y}}{\sqrt{N-1}}\right]^{2}}}$

Anova dua arah

$F_{A}=\frac{R K_{A}}{R K_{\text {dd }}} \quad F_{B}=\frac{R K_{B}}{R K_{\text {dd }}} \quad F_{A B}=\frac{R K_{A B}}{R K_{\text {d }}}$

(Hartono,2008:247)

Sebelum menguji rerata mana yang lebih baik, maka dilakukan uji normalitas, uji homogenitas dan uji t. Uji normalitas dilakukan dengan bantuan excel dengan rumus chi kuadrat. dengan kriteria $\mathrm{x}^{2}$ hitung lebih kecil dari $\mathrm{x}^{2}$ tabel 
(5\%) , maka data berdistribusi normal. berikut hasil pengelolahan datanya:

Tabel 1. Uji Normalitas Chi-Kuadrat Kelas Eksperimen dan kontrol

\begin{tabular}{lrc}
\hline Kelas & $\mathbf{X}_{\text {hitung }}$ & \multicolumn{1}{c}{$\mathbf{X}_{\text {tabel }}$} \\
\hline Eksperimen & 10.4 & 11.07 \\
Kontrol & 10.2 & 11.07
\end{tabular}

Bedasarkan tabel 1 diperoleh bahwa $\mathrm{x}^{2}$ hitung di kelas eksperimen dan kontrol lebih kecil dari $\mathrm{x}^{2}$ tabel $(5 \%)$ bedasarkan kriteria maka kelas eksperimen dan kelas kontrol berdistribusi normal.

Setelah diketahui data berdistribusi normal dilanjutkan dengan uji homogenitas kedua kelas. Uji homogenitas dilakukan bantuan excel dengan kriteria $\mathrm{F}_{\text {hitung }}$ lebih kecil dari $\mathrm{F}_{\text {tabel }}$, maka data berdistribusi homogen. berikut hasil pengelolahan datanya:

Tabel 2. Uji Homogenitas Eksperimen dan kontrol

\begin{tabular}{cc}
\hline $\mathbf{F}_{\text {hitung }}$ & $\mathbf{F}_{\text {tabel }}$ \\
\hline 1.123 & 1.8 \\
\hline
\end{tabular}

Bedasarkan tabel 2 diperoleh bahwa $\mathrm{F}$ hitung lebih kecil dari $\mathrm{F}$ tabel $(5 \%)$ bedasarkan kriteria maka kedua kelas homogen.

Selanjutnya akan diuji hipotesis I. Jika $t_{\text {hitung }}$ lebih kecil dari $\mathrm{t}_{\text {tabel }}(5 \%)$ maka $\mathrm{H}_{0}$ diterima dan sebalikanya. Adapun hipotesis I dalam penelitian ini sebagai berikut

$\mathrm{H}_{0}$ : Tidak Terdapat perbedaan kemampuan pemecahan masalah matematis antara siswa mengikuti pembelajaran strategi metakognitif dengan siswa yang mengikuti pembelajaran konvensional di MAN 1 Pekanbaru.

Ha: Terdapat perbedaan kemampuan pemecahan masalah matematis antara siswa mengikuti pembelajaran strategi metakognitif dengan siswa yang menggunakan pembelajaran konvensional di MAN 1 Pekanbaru.

Berikut hasil pengelolahan data dari hipotesis I:

Tabel 3. Uji t Eksperimen dan kontrol

\begin{tabular}{cc}
\hline $\mathbf{t}_{\text {hitung }}$ & $\mathbf{t}_{\text {tabel }}$ \\
\hline 3.309 & 1.9977 \\
\hline
\end{tabular}

Berdasarkan tabel 3 diperoleh bahwa $t_{\text {hitung }}$ lebih besar dari $t_{\text {tabel }}(5 \%)$ maka dapat disimpulkan terdapat perbedaan kemampuan pemecahan masalah matematis antara siswa mengikuti pembelajaran strategi metakognitif dengan siswa yang menggunakan pembelajaran konvensional di MAN 1 Pekanbaru.

Uji hipotesis II dan III menggunakan anova dua arah. dengan kriteria jika $\mathrm{F}_{\mathrm{hi}}$ lebih kecil dari $\mathrm{F}_{\mathrm{k}}$ maka $\mathrm{H}_{0}$ diterima dan sebalikanya. adapun hipotesis II dalam penelitian ini sebagai berikut:

$\mathrm{H}_{0}$ : Tidak terdapat perbedaan kemampuan pemecahan masalah matematis antara siswa yang memiliki kemandirian belajar tinggi, sedang dan rendah di MAN 1 Pekanbaru.

$\mathrm{H}_{\mathrm{a}}$ : Terdapat perbedaan kemampuan pemecahan masalah matematis antara siswa yang memiliki kemandirian belajar tinggi, sedang dan rendah di MAN 1 Pekanbaru.

Dan hipotesis III dalam penelitian ini sebagai berikut:

$\mathrm{H}_{0}$ : Tidak terdapat interaksi antara strategi metakognitif dan kemandirian belajar dalam mempengaruhi kemampuan pemecahan masalah matematis siswa di MAN 1 Pekanbaru.

$\mathrm{H}_{\mathrm{a}}$ : Terdapat interaksi antara strategi metakognitif dan kemandirian belajar dalam mempengaruhi kemampuan pemecahan masalah matematis siswa di MAN 1 Pekanbaru.

Berikut hasil pengelolahan data dari hipotesis II dan III:

Tabel 4. Uji Anova Dua Arah Eksperimen dan kontrol

\begin{tabular}{ccc}
\hline & $\mathbf{F}_{\mathbf{h}}$ & $\mathbf{F}_{\mathbf{k}}$ \\
\hline $\begin{array}{c}\text { Antar kolom } \\
\text { (Kemandirian } \\
\text { Belajar)B }\end{array}$ & 40.45 & 3.15 \\
$\begin{array}{c}\text { Interaksi Kemandirian } \\
\text { Belajar*Strategi } \\
(\mathbf{A} \times \mathbf{B})\end{array}$ & 0.47 & 3.15 \\
\hline
\end{tabular}

Berdasarkan tabel 4 diperoleh bahwa untuk hipotesis II $\mathrm{F}_{\text {hitung }}$ lebih besar dari $\mathrm{Ft}_{\text {abel }}$ maka dapat disimpulkan terdapat perbedaan kemampuan pemecahan masalah matematis antara siswa yang memiliki kemandirian belajar tinggi, sedang dan rendah. untuk hipotesis III

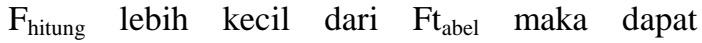
disimpulkan terdapat tidak terdapat interaksi antara strategi metakognitif dan kemandirian belajar dalam mempengaruhi kemampuan pemecahan masalah matematis siswa.

Pada awal pembelajaran di kelas eksperimen siswa mengalami kebingungan karena biasanya meraka dituntun dalam memilih strategi untuk memecahkan soal, namun dalam penerapan strategi metakognitif guru hanya mengajukkan pertanyaan untuk merangsang kemampuan kognitif siswa dan membebaskan siswa dalam memilih strategi. keberhasilan pada penelitian ini sejalan dengan penelitian dari Suratmi dan Agustina $(2017,183)$ dan penelitian 
yang dilakukan Ferida Dwi yang dilakukan pada siwa kelas VII yogyakarta $(2017,9)$

\section{SIMPULAN}

Berdasarkan hasil pengujian tersebut dapat menjawab rumusan masalah dari judul yang diangkat oleh peneliti yaitu Pengaruh Penerapan Pendekatan metakognitif terhadap Kemampuan pemecahan masalah matematis bedasarakan kemandirian belajar Siswa Madrasah Aliyah Negeri 1 Pekanbaru. Serta dapat disimpulkan bahwa terdapat pengaruh pembelajaran pendekatan metakognitif terhadap kemampuan pemecahan masalah matematis dan terdapat pengaruh kemandirian belajar terhadap pemecahan masalah matematis siswa.

\section{UCAPAN TERIMAKASIH}

Penulis mengucapkan terimakasih kepada Rektor Universitas Sultan Syarif Kasim Riau yang telah memberikan perijinan untuk melaksanakan penelitian ini. Selain itu penulis juga mengucapkan terimakasih kepada segenap tim Pengelola Jurnal Anargya yang telah memberikan kesempatan kepada penulis untuk mempublikasikan karya ilmiahnya

\section{DAFTAR PUSTAKA}

Arum, R. P. 2017. Deskripsi Kemampuan Metakognisi Siswa Sma Negeri 1 Sokaraja Dalam Menyelesaikan Soal Cerita Matematika Ditinjau Dari Kemandirian Belajar Siswa. Alphamath, 3 (1).

Delina, Sri dkk. 2015. Peningkatan Kemampuan Pemecahan Masalah Matematik Dan Kemandirian Belajar Siswa Smp Melalui Model Pembelajaran Berbasis Masalah. Jurnal Paradikma, 8 (3)

Depdiknas. 2008. Kurikulum Tingkat Satuan Pendidikan. Jakarta: Depdiknas.

Eviliyanida. 2010. Pemecahan Masalah Matematika. 1 (2)

Fatimah, A. E. 2016. Peningkatan Kemampuan Pemecahan Masalah Matematis Dan Kemandirian Belajar Siswa Smk Negeri 1 Percut Sei Tuan Melalui Pendekatan Differentiated Instruction. MES (Journal of Mathematics Education and Science), 2(1).

Hendriana, H. dan Utari S. 2014. Penilian Pembelajaran Matematika. Bandung: PT Refika Adiatama.
Hendriana, H dkk. 2017. Hard Skill Dan Soft Skill Matematik Siswa. Bandung: Refika Adiatama.

Hudojo, H. 1990. Strategi Pembelajaran Matemaika.Malang: IKIP Malang

Husamah dan Yanur S. 2013. Desain Pembelajaran Berbasis Pencapaian Kompetensi. Jakarta: Prestasi Pustaka.

Lai, Emily R. 2011. Metaconoyion: A Literature Review. Diakses 04 April 2018 (http://www.pearsonassesments.com/)

Lestari, K. E. dkk. 2017. Penelitian Pendidikan Matematika, Bandung: Rafika Adiatama.

Mawaddah, S dan Hana A. 2015. Kemampuan Pemecahan Masalah Matematis Siswa pada Pembelajaran Matematika dengan Menggunakan Model Pembelajaran Generatif di SMP. EDU-MAT Jurnal Pendidkan Matematika. 3(2)

OZSOY, Gokhan Aysegul ATMAN. 2009. The effect of Metacognitive strategi on mathematical problem solving achievement. Internasional Electronic Journal Of Elementaru Education, 1 (2).

Prasetyoningrum, F. D. 2017. Pengaruh Strategi Metakognitif Terhadap Kemampuan Pemecahan Masalah Matematis Siswa Kelas VIII di Smp Negeri 6 Yogyakarta, Jurnal Pendidikan Matematika, 6, (4)

Riduwan. 2010. Belajar Mudah (Penelitian Untuk Guru, Karyawan, dan Peneliti Pemula). Bandung:Alfabeta.

Risnawati dkk. 2016. Pengembangan Lks Pemecahan Masalah Kaidah Pencacahan dengan pendekatan Metakognitif Untuk Sma Kelas XI. $J P P M, 9$ (1).

Salvin, R. E. Psikologi Pendidika: Teori dan Praktek Jilid 2.Jakarta: PT Indeks.

Sanjaya, W. 2013. Penelitian Pendidikan: Jenis, Metode dan Prosedur . Jakarta: Kencana.

Santrock, J W. 2011. Psikologi Pendidikan, Jakarta: Kencana 47.

Sugiyono. 2014. Metode Penelitian Pendidikan: Pendekatan Kuantitatif, Kualitatif, dan $R \& D$. Bandung: Alfabeta.

Suherman, E. 2001. Strategi Pembelajaran Matematika Kontemporer, Bandung: JICA UPI.

Suratmi, G. S. P.. 2017. Pengaruh Strategi Metakognitif Terhadap Kemampuan Pemecahan Masalah Matematika Ditinjau Dari Persepsi Siswa Terhadap Pelajaran 
Anisah Meisura, Risnawati, dan Zubaidah Amir MZ

Anargya: Jurnal Pendidikan Matematika, Vol. 2 No.1, April 2019

Matematika. UNION: Jurnal Pendidikan

Matematika, 5(2): 183

Suryabata, Sumad. 2015. Metodologi Penelitian.

Jakarta: Rajawali Pers.

Yamin, Martinis. 2003. Strategi \& Metode dalam Model Pembeajaran.Jakarta: GP Press Group.

Zakaria, Effandi dkk. 2007. Trend Pengajaran dan Pembelajaran. Kuala Lumpur:PrinAD SDN BHD. 